\title{
Determinants of collaboration and innovation towards organization performance within Thailand's automotive parts industry
}

\author{
Winit Sueptaetrakun \\ SorasakTangthong
}

King Mongkut's Institute of Technology Ladkrabang, Thailand

\section{Keywords}

Collaboration, Innovation, Organization Performance, Cost Reduction, Customer Retention, Automotive Parts

\begin{abstract}
The objective of this study is to examine the collaboration and innovation influencing the organization performance of Thailand's automotive parts industry. Thailand's continuing economic growth has been partly attributed to the export automotive production industry that has also established Thailand as the automotive parts production base for ASEAN. Both industries have evolved into Thailand's key industries with the largest export values. Quantitative research method was employed to study 250 automotive parts entrepreneurs in Thailand. Questionnaires were used to collect data and SEM statistical modeling technique was used in the data analysis. The research found that organizations with significant emphasis on supplier, internal and customer collaboration to be able to create product, process, service and organization innovation that had significant impacts on the organization performance of Thailand's automotive parts industry regarding customer retention, employee satisfaction, cost reduction and organization growth.
\end{abstract}

Corresponding author: Winit Sueptaetrakun

Email address for corresponding author: industry2515@gmail.com

First submission received: $28^{\text {th }}$ March 2018

Revised submission received: $5^{\text {th }}$ May 2018

Accepted: 22 ${ }^{\text {nd }}$ May 2018

\section{Introduction}

Figure 1 shows that the global automotive industry continues to rapidly expand with the projected number of global automobile production of 106 million cars in 2017 or a compound annual growth rate (CAGR) of 5.02\% in 2019 (PWC, 2013). Therefore, the automotive parts industries vital to Thailand's economy and have been used as indicators for the country's economic growth.

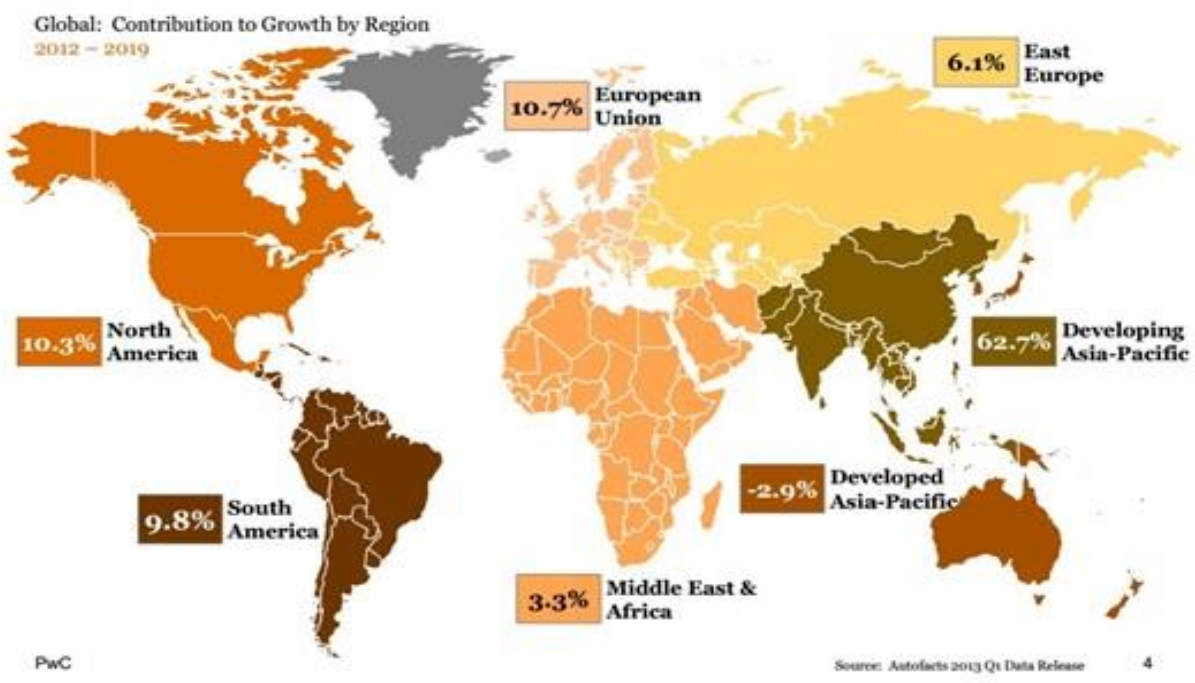

Figure 1: Regional Contribution to Growth 2012-2019 (percentage share)

Source: PWC (2013) 
Furthermore, Thailand has become a regional and world leader in the automotive industry, being the top producer in ASEAN and the 12th top producer in the world in 2015 (OICA, 2015). Based on the 2015 data, Thailand has also been the regional production base for motorcycle and automotive parts production.

\section{Structure of Thai automotive industry}

The core activities of the Thai automotive industry include 18 car makers in Thailand, who own trademarks and design the products and Tier 1 automotive parts producer, who are direct suppliers of automotive parts for automotive assembly factories. Tier 1 automotive parts are the high-quality automotive parts whose standards are determined by car manufacturers. At present, there is a total of 709 Tier 1 entrepreneurs, Tier 2 automotive parts producers and Tier 3 raw materials suppliers (BOI, 2015). Replacement Equipment Manufacturers (REM) are the group of producers who supply raw materials for Tier 1 producers or the group of producers who produce parts for distribution in the auto spare parts market. Equipment suppliers may be classified as Tier 1 entrepreneurs for certain products. There were 1,700 Tier 2 and Tier 3 manufacturers, the majority of which Thai entrepreneurs (SMEs) (BOI, 2015).

It was difficult for Thai entrepreneurs to take part in the designing and manufacturing of vehicles in the industry's core markets as the automotive production is generally determined by market situations and customer orders. For this reason, it is necessary for Thai automotive parts producers to cooperate with one another to increase production capacity of higher quality products at reduced costs (TAI, 2016). Collaboration with diverse allies-customers, suppliers, distributors and even competitors will be beneficial in terms of more innovation. However, such benefits depend on the different types of collaboration between different partners (Schøtt and Sedaghat, 2014). Collaboration with external sources can also increase the industry's business potential and can better respond to customer demand. Cheung, Myers \&Mentzer (2010) indicated that business knowledge, expertise, style, best practice and collaboration with allies in the supply chain will lead to other benefits such as product development and increasing work efficiency. Knowledge building is one of the factors that can improve development within the automotive industry and enhance organization performance. It can increase the Thai automotive industry's competitive advantage to become a strong automotive production base for Asia. However, this research gap to fill that has not been researched previous and a literature review helped identifying relevant factors that could be used in studying the industry's collaboration and in recommending appropriate types of collaboration and innovation for organizations in the automotive parts industry.

\section{Objectives of the study}

- To study the direct, indirect and combined influences of various variables on the organization performance within Thailand's automotive parts industry.

- To develop the types of collaboration and innovation that will influence organization performance within Thailand's automotive parts industry.

\section{Literature Review \\ Collaboration}

There has been extensive development in today's marketing activities and it has been demonstrated that an emphasis on marketing alone is not enough for the generating of the following value creation and value-creating marketing benefits: 1) the building of business relationships with customers, and 2) the building of business collaboration with customers (Prahalad \&Ramaswamy, 2000). There is a need to promote value-creating competency and value-creating activities in the benefit strategies of an organization (O'Cass\& Ngo, 2011). However, while more emphasis is given to key valuecreating activities the importance of work performance and the delivery of primary products to meet customer demand cannot be overlooked (Aron O'Cass and Liem Viet Ngo, 2012). It is possible that firms can utilize collaboration with producers or the knowledge gained from collaboration with external organizations to improve their work efficiency (Gupta \&Polonsky, 2014). Cristina Sancha et al., (2016) considered the primary objectives of collaboration to be for mutual improvement of work performance, relationship building, information exchange and mutual learning of business operation methods. Christina Oberg (2016) suggested that collaboration between individuals or business operations with different operation approaches could lead to mutual achievement or joint utilization of resources for 
alliance with organizations with mutual goals or mutual obligations (DeryaFindik and Berna Beyhan, 2015; Kuen-Hung Tsai, Teresa Tiaojung Hsu, 2014). Successful problem solutions through collaboration and exchange of information could result in innovation generated by collaboration with diverse allies such as customers, suppliers, distributors and even competitors. Nevertheless, innovation creation depends on the different forms of collaboration with different partners (Schøtt and Sedaghat, 2014). Different types of partner collaboration also benefit product innovation and process innovation (Fitjar and Rodríguez-Pose, 2013). Collaboration could initiate joint innovation with suppliers, customers, competitors, universities, consultants, private research institutes, public educational institutes, research associations and research technology organizations, resulting in more novel products in the markets (Tether, 2002). Ma Ding (2014) studied the impacts of collaboration within a supply chain and found that such collaboration and the ability to work together to create innovation and internal R\&D could promote relationships within the supply chain and higher level of innovation. A review of relevant literature produced the research model which are based on the following hypotheses:

Hypothesis 1: Collaboration has both direct and indirect influence over organization performance.

Hypothesis 2: Collaboration has direct influence over innovation.

\section{Innovation}

Innovation has been recognized as a crucial variable for the creation of values and retention of competitive advantage for an organization in today's highly competitive and fast changing business environment (Bilton\& Cummings, 2009). In general, innovation not only helps maximizing resource utilization by improving an organization's work efficiency and potential worthiness but organizations with higher number of innovations will be more successful in meeting customer demand and developing new ability for better work performance or higher profits (Sadikoglu\&Zehir, 2010). Innovation is as vital as the improvement of service quality in attaining work efficiency (Parasuraman, 2010). Building collaboration among individuals with diverse activities stimulates novelty and enhances competitive advantages. Organizations can benefit more from new ideas and innovations whereas R\&D will become more effective in achieving an organization's goals (Singh, 2008). However, Michael E. Porter (1985) stated that innovation is a creative means for the promotion of new commercial activities, novelty or new technology capable of meeting market demands and the approval or application of innovation to an organization's performance (Rogers, 2003). Daniel et al., (2011) maintained that innovation requires changes and utilization of existing knowledge through information and knowledge transfer among employees.

Therefore, organizations with innovation and new technology will be more effective in generating value-added products or services. Organizations must be continuously committed to self-development in terms of technical knowledge and technology. R\&D capability will strengthen an organization (Endang Chumaidiyah, 2012) while enable it to meet market demand for better business competitive edges. JiaSheng Lee (2010) discovered from his study that innovation capacity has direct influence on sustainable business competitiveness. Ipek Kocoglu et al., (2012) discovered that technological development and adjustment to cope with changing situations are essential to the building of sustainable competitive edges. The study focused on the ability to learn new technology and to generate R\&D in providing foundation for the creation of innovation and work efficiency of an organization. Derya Findik, Berna Beyhan (2015) studied the impacts of collaboration with external organizations on an organization's innovation performance with the objective of understanding the impacts of a company's collaboration with external organizations on the improving of its innovation performance. A review of relevant literature produced the research model which are based on the following hypotheses:

Hypothesis 3: Innovation has direct and positive influence over organization performance.

\section{Organization Performance}

At present, organizations have discovered that financial indicators alone are not enough for today's fierce business competition due to their various limitations. Non-financial indicators such as knowledge, organization reputation and image, trade mark, employee satisfaction and customer satisfaction are also important. Satisfied employees and customers will bring in future profits or create new technology and innovation capacity. Organization performance depends on its ability to achieve high 
quality employee collaboration (Lahiri et al., 2012). Therefore, Patrick Henry Ibeogu and Ali Ozturen (2015) asserted that measurement of operation efficiency or employee administration, promotion of employee potential and satisfaction, an increase in profits and sufficient expenditure for organizational operation are essential. Organizations with efficient collaboration will make valuable contributions to various aspects of marketing and financial organizations (Faems et al., 2005).

Moreover, measurement of work performance that helps determine frameworks for the measurement system and the comprehensive strategic administration of an organization should cover four of the following measurement perspectives (Robert S. Kaplan and David P. Norton, 1996, namely, financial perspective, customer perspective, internal business process perspective, learning and growth perspective. In addition, Gimenez et al., (2012) noted that collaboration in learning activities with suppliers of raw materials can enhance the social reputation of buyer companies. Gualandris et al., (2014) found changes in intra-organization practices helped improve buyer companies' sustainable organizations. It is also similarly believed that by collaborating with suppliers of raw materials (in such forms as joint training or joint operation in solving quality and safety shortcomings) will enable buyer companies to develop the necessary knowledge and skills for the improvement of the company's social organizations. Furthermore, Cristina Sancha et al., (2016) indicated that the achievement of supply chain goals with an emphasis on an organization's social responsibility and collaboration between buyers and suppliers of raw materials will lead to mutual improvement of its work performance, (Rune Dahl Fitjar and Andrés Rodríguez-Pose, 2013). The same principle applies to the maintenance of sustainable relationship with suppliers in the supply chain to cope with the external pressures affecting a company's organizations, improvement of sustainable processes to produce cost reduction and increase of profits from sale volumes (Grekova et al., 2016).

\section{Methodology \\ Questionnaire Design}

The research questionnaires were developed as a measurement tool based on the practical conceptual framework and definitions. The questionnaires were designed as a 7-Point Likert Scale (Likert, 1972) and were examined by five specialists for consistency of questionnaire items. The questionnaires' IOC values were calculated and items with IOC value above 0.5 were selected and included in the final set of questionnaires. The revised questionnaires were initially tested on 30 subjects in the sample group. Cronbach a-coefficient was used to check their internal consistency and to calculate their average correlations. Questionnaires on manifest or observed variables with over 0.70 reliability value are considered highly reliable (Hair et al., 2006). Cronbach's Alpha with a coefficient of reliability of 0.971 was used to measure the research's internal consistency.

\section{Data Collection}

AMOS program was used to analyze the relationship between variables and the Structural Equation Model (SEM) was used for the analysis of their structural and causal relationships. Advanced statistical methods were used in analyzing the correlations of the relationships between variables. The research's sample or population size was decided at 20 subjects per variable. Schumacker\& Lomax (2010) maintained that SEM analysis requires larger sample size than other analysis models to ensure accurate assessment and good representation of the population. Hair et al. (2006) stated that the sample group must be large enough for SEM analysis and normal curve data distribution. Data were collected from 250 Tier 1 automotive parts producers selected by a simple random sampling method. The informants include $\mathrm{MD}$, plant managers and division managers.

\section{Results}

\section{Measurement Model}

AMOS program was used to conduct a Confirmatory Factor Analysis (CFA) of the measurement model through an estimation of the maximum likelihood (ML) of model parameters. Acceptable and standardized criteria were used in the reflective analysis of measurement variables and goodness of fit measures as shown in Table 1. 
Table 1: Validation criteria and theory of Goodness of fit

\begin{tabular}{|l|l|l|}
\hline Component & Indicator & Criteria \\
\hline Chi-square & $\chi^{2}$ & Ns. $(p>0.05)$ \\
\hline Relative Chi-square & $\chi^{2} / \mathrm{df}$ & $\chi^{2} / \mathrm{df}<2.00$ \\
\hline Goodness of Fit Index & GFI & $>0.90$ \\
\hline Comparative Fit Index & CFI & $>.95$ \\
\hline Normal Fit Index & NFI & $>0.90$ \\
\hline Adjusted Goodness of Fit Index & AGFI & $>0.90$ \\
\hline Root Mean Square Error of Approximation & RMSEA & $\leq 0.05$ \\
\hline
\end{tabular}

Source: Schumaker \& Lomax (2010); Hair et al., (2006)

\section{Results of the Structural Equation Model Analysis}

Structural equation model analysis is a multivariate statistical analysis technique that combines factor analysis and multiple regression analysis together. The researchers found this technique useful for the checking of the structural relationships between variables which could be carried out in a single analysis (Hair et al., 2006). AMOS statistical program was used for SEM analysis and found Collaboration to have the standard regression weights of $0.848-890$ and the variation ratio ( $\mathrm{R}^{2}$ or Squared Multiple Correlation) of 0.719-0.792; Innovation was found to have the standard regression weights of $0.755-0.913$ and the variation ratio ( $\mathrm{R}^{2}$ or Squared Multiple Correlation) of 0.569-0.834; Organization Performance was found to have the standard regression weights of $0.792-0.952$ and the variation ratio $\left(\mathrm{R}^{2}\right.$ or Squared Multiple Correlation) of 0.627-0.907 (Table 2).

Table 2: Relative influence of items (standardized regression weights)

\begin{tabular}{|c|c|c|c|c|c|c|}
\hline \multicolumn{2}{|c|}{ Relationship between variables } & \multirow{2}{*}{$\begin{array}{l}\text { Standard Regression } \\
\text { Weights } \\
.845\end{array}$} & \multirow{2}{*}{\begin{tabular}{|l|} 
S.E. \\
.056 \\
\end{tabular}} & \multirow{2}{*}{$\begin{array}{l}\text { Squared Multiple } \\
\text { Correlations } \\
.714\end{array}$} & \multirow{2}{*}{$\begin{array}{l}\text { C.R. } \\
14.974\end{array}$} & \multirow{2}{*}{$\begin{array}{l}\mathrm{P} \\
\\
* * *\end{array}$} \\
\hline Innovation & <--- Collaboration & & & & & \\
\hline Performance & $<--\quad$ Collaboration & .164 & .083 & .855 & 1.988 & .047 \\
\hline Performance & $\begin{array}{ll}<--- & \text { Innovation }\end{array}$ & .781 & .089 & - & 8.954 & $* * *$ \\
\hline Organization & $\begin{array}{ll}<-- & \text { Innovation }\end{array}$ & .874 & .050 & .764 & 20.396 & $* * *$ \\
\hline Service & $<---\quad$ Innovation & .763 & .061 & .582 & 15.406 & $* * *$ \\
\hline Process & $<-<--$ Innovation & .913 & - & .834 & - & - \\
\hline Product & $<---\quad$ Innovation & .755 & .063 & .569 & 15.252 & $* * *$ \\
\hline Retention & <--- Performance & .792 & .042 & .627 & 18.086 & $* * *$ \\
\hline Employee & <--- $\quad$ Performance & .840 & .040 & .705 & 20.663 & $* * *$ \\
\hline Cost & $\begin{array}{ll}<-- & \text { Performance }\end{array}$ & .952 & - & .907 & - & - \\
\hline
\end{tabular}




\begin{tabular}{|c|c|c|c|c|c|c|c|}
\hline Growth & $<--$ & Performance & .847 & .045 & .718 & 21.139 & $* * *$ \\
\hline Internal & <--- & Collaboration & .890 & .058 & .792 & 16.541 & $* * *$ \\
\hline Supplier & <--- & Collaboration & .865 & .077 & .749 & 15.950 & $* * *$ \\
\hline Customer & $<--$ & Collaboration & .848 & - & .719 & - & - \\
\hline
\end{tabular}

Note. ${ }^{* * *}$ The level of statistical significance .01

A consistency analysis of the research's conceptual framework and empirical data found them to be model fit (Fig. 2). The test results were as follows: Chi-square $\left(\chi^{2}\right)=42.006, \mathrm{df}=32, \mathrm{p}=.111, \mathrm{CMIN} / \mathrm{DF}\left(\chi^{2} / \mathrm{df}\right.$ ) $=1.313, \mathrm{GFI}=.970, \mathrm{CFI}=.996, \mathrm{AGFI}=.938, \mathrm{NFI}=.984$ and $\mathrm{RMSEA}=.035$.

Results of the Structural Equation Model analysis were as follows:

Innovation $=0.85$ Collaboration, $\mathrm{R}^{2}=0.71$

Performance $=0.16$ Collaboration +0.78 Innovation, $\mathrm{R}^{2}=0.85$

\section{Hypothesis testing results}

Hypothesis testing with the use of $t$-Value (C.R.), p-Value and calculation of the correlations of each pair of variables together with an assessment of the influence of variables obtained from the standardized regression coefficients (coef.) of the pair of variables in each hypothesis were found to have statistically significant C.R. (t-test) values, all of which were higher than 1.96. This means the analysis results confirm all research hypotheses. The results of the hypothesis testing and variable influence testing are shown in Table 3.

Hypothesis 1: Collaboration has direct and positive influence on organization performance. The hypothesis testing results revealed a standardized regression coefficient of 0.164 (coef. $=0.164$ ). This hypothesis is, therefore, true and is statistically significant at $\mathrm{p}<0.05$.

Hypothesis 2: Collaboration has direct and positive influence on innovation. The hypothesis testing results revealed a standardized regression coefficient of 0.845 (coef. $=0.845$ ). The hypothesis is, therefore, true and is statistically significant at $\mathrm{p}<0.01$.

Hypothesis 3: Innovation has direct and positive influence on organization performance. The hypothesis testing results revealed a standardized regression coefficient of 0.781 (coef. $=0.781$ ). The hypothesis is, therefore, true and is statistically significant at $\mathrm{p}<0.01$.

Table 3: Results from the hypotheses testing on Organization Performance

\begin{tabular}{lcccccc}
\hline Hypothesis & coef. & t-test & TE & DE & IE & Results \\
\hline H1: Performance <---Collaboration & $0.164^{*}$ & 1.988 & 0.825 & 0.164 & 0.660 & Supported \\
H2: Innovation <--- Collaboration & $0.845^{* *}$ & 14.974 & 0.845 & 0.845 & - & Supported \\
H3: Performance <---Innovation & $0.781^{* *}$ & 8.952 & 0.781 & 0.781 & - & Supported
\end{tabular}

Note: * significant $\mathrm{p}<.05,{ }^{* *}$ significant at $\mathrm{p}<.01$, Coefficient refers to the Beta $(\beta)$

TE: Total effects, DE: Direct effects, IE: Indirect effects, Coefficient: coef. 


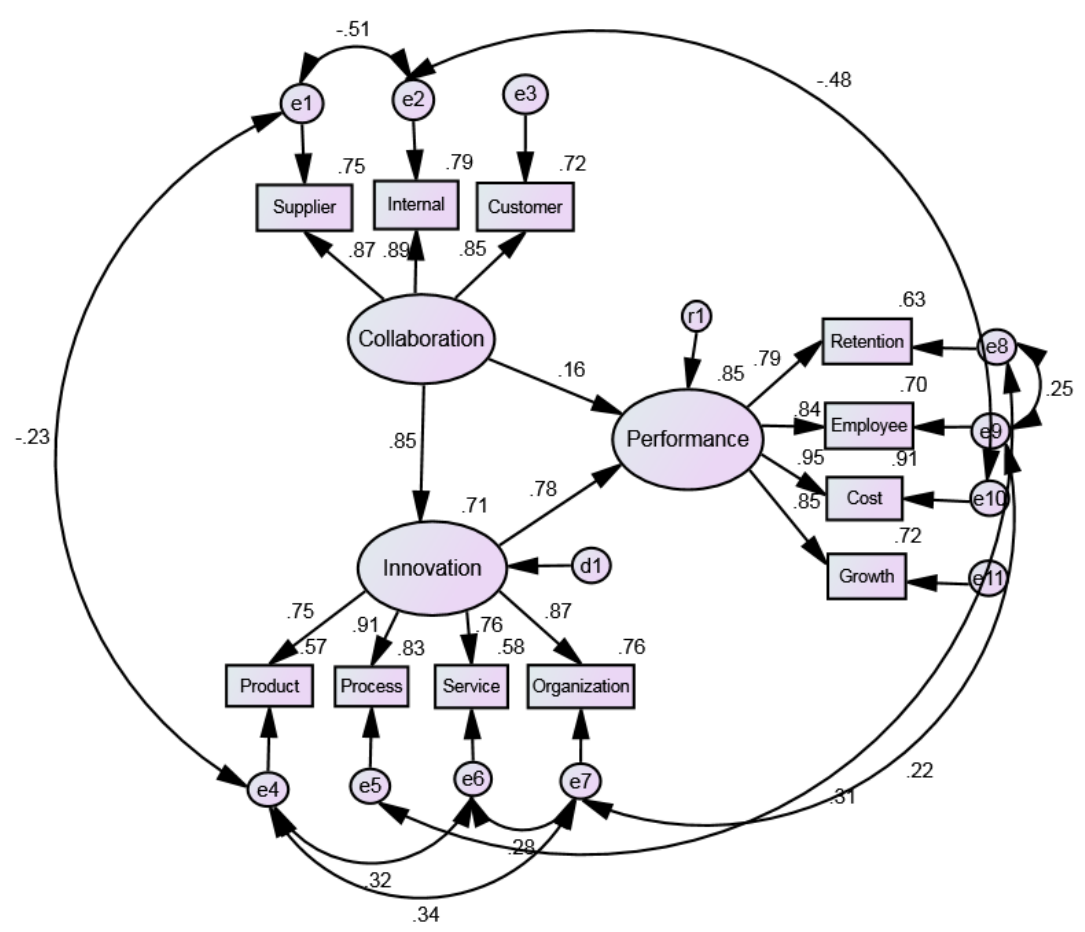

Chi-square $\left(\chi^{2}\right)=42.006, \mathrm{df}=32, \mathrm{p}=.111, \mathrm{CMIN} / \mathrm{DF}\left(\chi^{2} / \mathrm{df}\right)==1.313, \mathrm{GFI}=.970, \mathrm{CFI}=.996, \mathrm{AGFI}=.938, \mathrm{NFI}=.984$ and $\mathrm{RMSEA}=.035$

\section{Figure 2: Final Model}

\section{Discussion and Implementation}

The research found collaboration to have direct and positive influence on organization performance which is consistent with the findings of Grekova et al., (2016) on the influence of supplier-customer collaboration on organization performance. Grekova et al., (2016) found that the opportunity for sustainable growth of a firm was related to the sustainable relationships between the firm and its suppliers in the supply chain. Improvement of a firm's internal process to cope with external pressures on its performance also resulted in cost reduction and profit improvement through increasing sales volumes. Sriram Narayanan et al., (2015) found collaboration to lead to positive benefits and improved organization performance through the creation of buyer-distributor relationships, flexibility of collaboration and organization performance. However, Ilker Murat Ar and Birdogan Baki (2011) examined the relationships between R\&D strategies, endorsement of high-ranking executives, customer-centered approach, organizational learning and creativity capacity, supplier relations and innovation and found them to also have impacts on organization performance.

The research found collaboration to have direct and positive influence on innovation which is consistent with the research findings of Thomas Schøtt (2016) who found that firms could benefit from the establishing of process and product innovation networks. This research discovered that external collaboration could improve the innovation performance of a firm. Competitive collaboration and all types of collaboration had positive influences on the innovation performance of a firm. However, the impacts of external collaboration vary with the types of innovation involved. Un \& Asakawa (2015) found R\&D collaboration with suppliers and universities to have more positive impacts than process innovation. Derya Findik, Berna Beyhan (2015) studied the impacts of collaboration with external organizations on the innovation performance of a firm with the objective of understanding the impact of such collaboration on the innovation performance of a firm. They found that endorsement of collaboration with external organizations helped improve the innovation, product and marketing capacity of a firm. Such collaboration also improved the production process of a firm. Ma Ding (2014) also found collaboration to have impacts on the supply chain and on the creation of environmental-friendly innovation.

The research found the innovation to have positive influence on organization performance which is consistent with the findings of a study by Krishnaswamy et al., (2014) on the types of technological innovation influencing the growth of SMEs in the automotive parts industry. They found these business operators to have 
recognized the marketing opportunities that could arise from the promotion of a firm's technological capacity through external collaboration. They had modified their technological innovation to meet customer demand before placing products in the market. The key aspect of such innovation lied in a firm's continuous and systematic collaboration with customers to ensure business growth and increasing sales volumes. Wawan Dhewanto et al., (2012) studied the impacts of the innovation capacity of communication technology and its association to the organization performance of various groups in the value chain who shared resources. They also studied the association between innovation capacity and organization performance. However, a study by Mubeyyen Tepe Kucukoglu et al., (2015) indicated that environmental innovation and the impacts of an organization performance on the environment affected the work efficiency of a firm.

Therefore, it is essential that organizations must engage in all forms of collaboration in order to outperform their competitors in terms of financial and marketing performance, meeting customer demand, sales volumes, profitmaking capacity and return on investment (ROI). Compared to competitors in the same industry, organizations with higher collaboration efficiency can do better in various aspects of marketing and financial performance (Faems et al., 2005). Nevertheless, collaboration for system and inherent knowledge transfer are vital for organizational improvement, creativity, corporate innovation as well as the reduction or production costs, time and risks. Collaboration will result in higher levels of value creation and customer satisfaction. Therefore, firms that put more emphasis on collaboration to induce performance improvement and business development will be able to achieve process innovation, product innovation, service innovation and organization innovation. Such organizational modification will enable firms to maintain sustainable competitive advantages in the industry.

\section{Conclusions}

In competing with other countries with highly-competitive automotive industry in the region, Thailand must give special importance to the creating of more competitive edges in terms of product costs, quality and punctual goods delivery. However, the present study on Thailand's automotive parts industry found existing entrepreneurs to have relatively low level of collaboration. Significant government support and R\&D efforts are still lacking and result in the industry's currently incremental innovation. It is essential that the industry pay more attention to the establishment of key business collaboration and business clusters. Major findings of the present research on Determinants of Collaboration and Innovation Towards Organization Performance within Thailand's Automotive Parts industry are as follows: Collaboration is a crucial factor for the introduction of process, product, service and organization innovation that will have greater impacts on organization performance and the industry's capacity to produce higher quality automotive parts at lower costs. It will also help the industry in retaining its old customer bases and in creating employee satisfaction. The government must introduce a more balanced economic structure with stronger collaboration networking with both local and foreign automotive industries. It must encourage better knowledge and technological transfer to produce personnel with new skills and creative thinking process. Entrepreneurs must be encouraged to adjust themselves in preparation for future competition in which they must be able to determine proper directions and strategies for the Thai automotive parts industry.

\section{Research limitations and further research}

Although the study results present the theoretical and organization performance of the automotive industry. There are some limitations which should be mentioned and noted. The first, there are many variables that may predict the organization performance of the automotive industry at the present time. However, this study was limited to the collaboration and innovation of organization performance in the automotive industry only. According to the literature review, the research model explained $85 \%$ of all variances in the organization performance of the automotive industry. This means that there are other latent variables that explain the remaining variances. The scope of research was limited to organization of the automotive industry in Thailand. In order to overcome these limitations, this study recommends future studies using other variables that can predict the organization performance of the automotive industry in Thailand. There may be positive influences of the other variables. The future research should also consider a wider scope and include the automotive industries of other countries.

\section{References}

Aron O'Cass and Liem Viet Ngo. 2012, “Creating superior customer value for B2B firms through supplier firm capabilities", Industrial Marketing Management, 41, pp.125-135.

Bilton, C., \& Cummings, S. 2009, Creative strategy: From innovation to sustainable advantage, John Wiley \& Sons Ltd.

BOI. 2015, Thailand: Global Green Automotive Production Base, Retrieved January 15, 2016, from http:/ / aseanup.com/thailand-automotive-industry-overview/

Cheung, M., Myers, M. B., \& Mentzer, J. T. 2010, “Does relationship learning lead to relationship value? A crossnational supply chain investigation", Journal of Operations Management, 28(6), pp.472-487.

Cristina Sancha, Cristina Gimenez, Vicenta Sierra. 2016, “Achieving a socially responsible supply chain through assessment and collaboration”, Journal of Cleaner Production, 112, pp.1934-1947. 
Daniel Jiménez-Jiménez, Raquel Sanz-Valle. 2011, “Innovation, organizational learning, and performance”, Journal of Business Research, 64, pp.408-417.

Derya Findik and Berna Beyhan. 2015, “The Impact of External Collaborations on Firm Innovation Performance: Evidence from Turkey", Procedia - Social and Behavioral Sciences, 195, pp.1425 - 1434.

Endang Chumaidiyah. 2012, "The Technology, Technical Skill, and R\&D Capability in Increasing Profitability on Indonesia Telecommunication Services Companies", Procedia Economics and Finance, 4, pp.110 - 119.

Faems, D., Van Looy, B. \& Debackere, K. 2005, “Interorganizational collaboration and innovation: toward a portfolio approach", Journal of Product Innovation Management, 22, pp.238-250.

Fitjar, R.D., Rodríguez-Pose, A. 2013, "Firm collaboration and modes of innovation in Norway", Res. Policy, 42, pp.128-138.

Gimenez, C., Sierra, V., Rodon, J. 2012, “Sustainable operations: their impact on the triple bottom line”, Int. J. Prod. Econ., 140, pp.149-159.

Gualandris, J., Golini, R., Kalchschmidt, M. 2014, “Do supply management and global sourcing matter for firm sustainability performance?", Int. Study. Supply Chain Manag. Int. J., 19(3), pp.258-274.

Gupta, S., \&Polonsky, M. 2014, “Interfirm learning and knowledge-sharing in multinational networks: An outsourced organization's perspective" Journal of Business Research, 67(4), pp.615-622.

Hair, J.F., Black W.C. Babin, B.J., Anderson, R.E. and Tatham, R.I. 2006, Multivariate Data Analysis, 6th ed. Upper Saddle River, NJ: Prentice-Hall.

Ilker Murat Ar and BirdoganBaki. 2011, “Antecedents and performance impacts of product versus process innovation: Empirical evidence from SMEs located in Turkish science and technology park", European Journal of Innovation Management, 14(2), pp.172-206.

Jia-Sheng Lee. 2010, “A research in relating entrepreneurship, marketing capability, innovation capability and sustained competitive advantage", Journal of Business Economics Research- September 8(9), pp.109-119.

K. Grekova, R.J. Calantone, H.J. Bremmers, J.H. Trienekens, S.W.F. Omta. 2016, “How environmental collaboration with suppliers and customers influences firm performance: evidence from Dutch food and beverage processors", Journal of Cleaner Production, 112, pp.1861-1871.

K.N. Krishnaswamy, M. Mathirajan, M.H. BalaSubrahmanya. 2014, “Technological innovations and its influence on the growth of auto component SMEs of Bangalore: A case study approach" Technology in Society, 38, pp.18-31.

Kuen-Hung Tsai, Teresa Tiaojung Hsu. 2014, "Cross-Functional collaboration, competitive intensity, knowledge integration mechanisms, and new product performance: A mediated moderation model", Industrial Marketing Management, 43, pp.293-303.

Lahiri, S., Kedia, B.L., Mukherjee, D. 2012), "The impact of management capability on the resource-performance linkage: examining Indian outsourcing providers", Journal of World Business, 47(1), pp.145-155.

Likert, R. 1972, Likert Technique for Attitude Measurement. In: Social Psychology: Experimentation, Theory, Research, Sahakian, W.S. (Ed.). Intext Educational Publishers, Scranton, USA., ISBN-13: 9780700223879, pp.101-119.

Ma Ding. 2014, "Supply Chain Collaboration toward Eco-innovation: an SEM Analysis of the Inner Mechanism", IEEE, pp.129-134.

Michael E. Porter. 1985, Competitive Advantage Creating and Sustaining Superior Performance. New York, The Free Press.

MubeyyenTepeKucukoglu, R. Ibrahim Pinar. 2015, “Positive Influences of Green Innovation on Company Performance", Procedia - Social and Behavioral Sciences, 195, pp.1232 - 1237.

O'Cass, A., \& Ngo, L. V. 2011, “Examining the Firm's Value Creation Process: A Managerial Perspective of the Firm's Value Offering Strategy and Performance", British Journal of Management, 22(4), pp.646-671.

OICA. 2015 Production Statistics. Retrieved September 3, 2016, from http://www.oica.net/category/productionstatistics/2015-statistics/

Parasuraman, A. 2010, "Service productivity, quality and innovation: Implications for service-design practice and research", International Journal of Quality and Service Sciences, 2, pp.277-286.

Prahalad, C. K., \&Ramaswamy, V. 2000, “Co-opting customer competence”, Harvard Business Review, 78, pp.79-87.

Patrick HenryIbeogu and Ali Ozturen. 2015, "Perception of Justice in Performance Appraisal and Effect on Satisfaction: Empirical Findings from Northern Cyprus Banks", Procedia Economics and Finance, 23, pp.964 969.

PWC. 2013, Automobiles: The economic outlook and employment situation. Retrieved January 10, 2015, from http:/ / tinyurl.com/nopovcr.

Robert S. Kaplan and David P. Norton. 1996, "Using the Balanced Scorecard as a Strategic Management System", Harvard Business Review (January-February 1996), 76.

Rogers, E.M. 2003, Diffusion of innovations, 5th ed. The Free Press. New York. NY.

Rune Dahl Fitjar, Andrés Rodríguez-Pose. 2013, "Firm collaboration and modes of innovation in Norway", Research Policy, 42, pp.128- 138 . 
Sadikoglu, E., \&Zehir, C. 2010, “Investigating the effects of innovation and employee performance on the relationship between total quality management practices and firm performance: An empirical study of Turkish firms", International Journal of Production Economics, 127, pp.13-26.

Schøtt, T., Sedaghat, M. 2014, “Innovation embedded in entrepreneurs' networks and national educational systems: a global study", Small Bus. Econ, 43(2), pp.463-476.

Schumacker, R.E. and R.G. Lomax. 2010, A Beginners Guide to Structural Equation Modeling. New York, Routledge. ISBN-13: 9781841698915.

Singh, J. 2008, "Distributed R\&D, cross-regional knowledge integration and quality of innovative output", Research Policy, 37, pp.77-96.

Sriram Narayanan, Ram Narasimhan, Tobias Schoenherr. 2015, “Assessing the contingent effects of collaboration on agility performance in buyer-supplier relationships", Journal of Operations Management, 33-34, pp.140-154.

Tether, B. 2002, "Who co-operates for innovation, and why: an empirical analysis", Res. Policy, 31, pp.947-967.

TAI. 2016, Master Plan for Automotive Industry 2012 - 2016. Ministry of Industry, Retrieved September 3, 2016, from http:/ / tinyurl.com/o6cs4xs

Thomas Schøtt and Kent Wickstrøm Jensen. 2016, “Firms' innovation benefiting from networking and institutional support: A global analysis of national and firm effects", Research Policy, 45, pp.1233-1246.

Un, C.A., \& Asakawa, K. 2015, “Types of R\&D collaborations and process innovation: The benefit of collaborating upstream in the knowledge chain" Journal of Product Innovation Management, 32, pp.138-153.

Wawan Dhewant, Eko Agus Prasetio, Sudrajati Ratnaningtyas, Sri Herliana, Rendra Chaerudin, QorriAina, R. Bayuningrat H., EvyRachmawaty. 2012, “Moderating Effect of Cluster on Firm's Innovation Capability and Business Performance: A Conceptual Framework", Procedia-Social and Behavioral Sciences, 65, pp.867 - 872. 